6-3870 Nortje $N$, de Vos $H M$ \& le Roux $M C$

\title{
THE ATTITUDES OF OLDER SOUTH AFRICANS TOWARDS EUTHANASIA
}

Dr HM de Vos, lecturer, (Supervisor of Research) and Ms MC le Roux, senior research assistant, Department of Psychology, University of Stellenbosch. Mr N Nortje was a student

\begin{abstract}
The purpose of this study was to determine the attitudes of older South African adults (65 years and older) towards euthanasia. The subjects of the study were people 65 years of age and older who resided in homes for the aged within the rural and urban areas of the Cape Town Metropolis. An equal number of subjects from the African, Coloured and European communities were randomly selected. A biographical questionnaire, the Euthanasia Attitude Scale and the Purpose In Life Test were administered. The influence of four variables - namely age, ethnicity, meaning in life and health - was investigated. A Pearson correlation coefficient analysis and a one-way ANOVA analysis were used. Age was the only variable found to have a significant correlation with euthanasia. The findings are discussed and certain recommendations are made.
\end{abstract}

Since older people are often perceived as neither useful to others or in control of their lives (Kastenbaum \& Schmitz-Scherzer, 1987), they frequently receive no more than last-minute intervention in emergency departments. Society is increasingly dedicated to speed and efficiency, and suffering is no longer viewed as an acceptable and an inevitable part of living. Euthanasia is often seen as a process whereby death and suffering are made tolerable and decent (Cheney, 1996). Very little research has so far been undertaken on the attitudes of older adults towards euthanasia, and there is a need to study the influence of demographic factors on their views (Cicerelli, 1997).

Due to great technological improvements in the medical field, better health care (such as the prevention and treatment of many childhood illnesses), and political and economic infrastructure reforms (Hayflick, 1987; Seale \& Addington-Hall, 1994; Van der Maas, Van Delden, Pijnenborg \& Looman, 1991), the life expectancy of the average South African has risen from 49 (Van Rensburg, Pretorius \& Fourie, 1992) in the 1940s to 70 years in the 1990s (Development Bank of South Africa, 1996).

The increase in the ageing population, the development and expansion of life-prolonging technologies, and the generational and cultural changes in the attitudes of patients are fast creating grave moral dilemmas for society. One such a dilemma is the universally debated issue of the ethics surrounding medical decisions to end life. A prime concern is the matter of euthanasia - an act or omission intended to shorten life, carried out by a person other than the person concerned, upon the request of the latter (Hessing, Blad \& Pieterman, 1996). Many authors (Chochinov \& Wilson, 1995; Latimer \& McGregor, 1994) are of the opinion that the ethical and legal status of euthanasia and physician-assisted suicide need to be re-examined. Such a re-assessment would need to pay special attention to how ethnic diversity (Hessing et al., 1996; Lee, Kleinbach, Hu, Peng \& Chen, 1996), different belief systems and attitudes toward life and death will affect a person's views on euthanasia (Comaz-Diaz \& Griffith, 1988; Hessing et al., 1996; Lee et al., 1996; MacDonald, 1998).

Attitudes towards life and death are socio-culturally based and ethno-culturally specific (ComazDiaz \& Griffith, 1988; Hessing et al., 1996; Lee et al., 1996). Given the diversity of the South 
African population, it is therefore important to include ethnicity in the study, discussion and assessment of attitudes towards euthanasia.

Although culture presents the individual with norms and guidelines in terms of which life may find meaning (Baumeister, 1991), dealing with euthanasia is more complicated than simply voicing an opinion in favour of or against it. This attitudinal complexity is the result of various factors, which have a great influence on most individuals' view of euthanasia. These factors include cultural and religious values and customs, economic situation, medical developments and legal issues (Bachman, Alcser, Doukas, Lichtenstein, Corning, \& Brody, 1996; Blendon, Szalay, \& Knox, 1992; Cicerelli, 1997; Darley, Loeb \& Hunter, 1996; Ho \& Penney, 1992; Lee et al., 1996; Scott, 1998).

South Africa is presently facing proposed changes to the legislation on euthanasia, similar to those recently accepted in the Netherlands,. In the light of a request by the South African Voluntary Euthanasia Society (SAVES), the South African Law Commission (SALC) issued a discussion paper suggesting changes to the legislation favouring voluntary euthanasia (South African Law Commission, 1997).

Given the pending legal reforms, the increase in the elderly population, the emergence of improved life-preserving techniques, issues concerning personal autonomy (Seale \& AddingtonHall, 1994), the need for more studies (Cicerelli, 1997; Koenig 1993; Nance \& Ruby, 1996), and the lack of any comparative research data relating to the older South African population, it is clearly of great importance to study the attitudes of older adults (65 years and older) towards euthanasia. Such a study would need to focus on the influence of variables such as age, ethnicity, and health.

The purpose of this study is to establish the influence of cultural background, purpose in life, health and age on the attitudes of older adults towards euthanasia.

The present study was limited to the Cape Town Metropolitan area. The discussion and results relating to the African part of the sample of this study were limited to the Xhosa ethnic group, since it is the largest African group in the Western Cape.

\section{METHOD}

\section{Participants}

A list of homes for the aged in the Western Cape Metropolis was obtained from the provincial administration of the Western Cape's department of social welfare. Eight homes were selected by a simple random sampling method (Babbie \& Mouton, 2001). These homes were representative of all socio-economic and ethnic groups of the general, elderly population in the Western Cape. One hundred and twenty respondents were identified from these homes. Older adults who were found not to be of sound mind were excluded from this study. Table 1 provides the biographical information of these 120 adults. 
TABLE 1

RESULTS OF THE BIOGRAPHICAL QUESTIONNAIRE (N=120)

\begin{tabular}{|c|c|c|c|}
\hline \multirow{3}{*}{ Sex } & & Frequency & Percentage \\
\hline & Male & 39 & 32.5 \\
\hline & Female & 81 & 67.5 \\
\hline \multirow[t]{5}{*}{ Age } & $65-69$ & 27 & 22.5 \\
\hline & $70-74$ & 27 & 22.5 \\
\hline & $75-79$ & 23 & 19.2 \\
\hline & $80-84$ & 22 & 18.3 \\
\hline & $85+$ & 21 & 17.5 \\
\hline \multirow[t]{4}{*}{ Language } & Afrikaans & 47 & 39.2 \\
\hline & English & 38 & 31.7 \\
\hline & Xhosa & 33 & 27.5 \\
\hline & Other & 02 & 01.7 \\
\hline \multirow[t]{3}{*}{ Ethic Origin } & African & 40 & 33.3 \\
\hline & Coloured & 40 & 33.3 \\
\hline & European & 40 & 33.3 \\
\hline \multirow[t]{5}{*}{ Marital Status } & Married & 17 & 14.2 \\
\hline & Widowed & 58 & 48.3 \\
\hline & Divorced & 11 & 09.2 \\
\hline & Separated & 04 & 03.3 \\
\hline & Never married & 30 & 25.0 \\
\hline \multirow[t]{5}{*}{ Health } & Excellent & 19 & 15.8 \\
\hline & Good & 47 & 39.2 \\
\hline & Fair & 33 & 27.5 \\
\hline & Poor & 20 & 16.7 \\
\hline & Terminally ill & 01 & 00.8 \\
\hline \multirow[t]{5}{*}{ Religious belief } & Roman Catholic & 19 & 15.8 \\
\hline & Protestant & 97 & 80.8 \\
\hline & African & 01 & 00.8 \\
\hline & Agnostic & 01 & 00.8 \\
\hline & Other & 02 & 01.7 \\
\hline
\end{tabular}

Participation in the study was voluntary and anonymous.

This study investigated the variations in cultural, religious and health backgrounds as well as purpose and meaning in life, in order to establish the influence of such variables on the attitudes of older adults towards euthanasia. However, due to the limited nature of the literature relating to cross-cultural investigations into the attitudes of older adults towards euthanasia, it was decided to postulate research questions rather than to formulate hypotheses. The following questions were derived from the literature:

- Does age influence a person's view towards euthanasia?

- Do people from different ethnic groups hold different views regarding euthanasia?

- Do people who are of poor health favour euthanasia more than people of good health? 


\section{Measuring Instruments}

Each respondent was asked to complete three questionnaires, namely a Demographic Questionnaire, The Purpose In Life Test (PIL) and the Euthanasia Attitude Scale (EAS).

(a) Biographical Questionnaire: Participants were asked to report their age, language, ethnic origin, academic background, marital status, religious belief, level of religious activity, health status, health interfering with normal activities, and the presence of unbearable pain.

(b) Euthanasia Attitude Scale (EAS) (Holloway, Hayslip, Murdock, Maloy, Servaty, Henard, Lopez, Lysaght, Moreno, Moroney, Smith, \& White, 1995): The EAS investigates issues surrounding both active and passive euthanasia, legal issues, values and ethical factors. The questionnaire consists of 35 seven-point Likert-type questions, of which half were written in the affirmative (pro-euthanasia) and half in the negative (anti-euthanasia) form. The questionnaire furthermore deals with a variety of issues surrounding both active and passive euthanasia, such as the status of brain-dead persons, life-extending technology, and ethical and legal issues. Higher scores indicated more positive, accepting attitudes towards the practice of euthanasia. Although the EAS was standardised for the American population, the reliability score for this specific study had an Alpha coefficient of 0.55.

(c) Purpose in Life (PIL) (Crumbaugh \& Maholick, 1969): The PIL test is an attitude test measuring Victor Frankl's basic concept of an "existential vacuum". The PIL consists of 20 scaled-item questions. Each question is a statement with two opposites to choose from. The respondent has to place him- or herself on a seven-point scale closest to the answer which represents him or her the best. The questionnaire has excellent psychometric properties with a high reliability Alpha coefficient ranging between 0.81 and 0.92 . However, the PIL test was not standardised for the South African population, because raw scores were used, but the researcher found that the test's reliability score for this specific study had an Alpha coefficient of 0.72 .

\section{RESULTS}

The aim of this study was to research older adults' view towards euthanasia and the influence of specific variables on these views.

The mean score and standard deviation of each demographic variable towards euthanasia appear in Table 2. 
TABLE 2

DESCRIPTIVE ANALYSIS OF EUTHANASIA ATTITUDE SCALE AND THE BIOGRAPHICAL VARIABLES

\begin{tabular}{|c|c|c|c|}
\hline \multicolumn{2}{|l|}{ Variable } & $\bar{X}$ & SD \\
\hline \multirow[t]{5}{*}{ Age } & $65-69$ & 80.44 & 19.04 \\
\hline & $70-74$ & 83.33 & 18.86 \\
\hline & $75-79$ & 89.70 & 16.66 \\
\hline & $80-84$ & 90.27 & 20.21 \\
\hline & $85+$ & 91.57 & 17.60 \\
\hline \multirow[t]{3}{*}{ Ethnic Origin } & African & 84.98 & 20.94 \\
\hline & Coloured & 84.55 & 17.53 \\
\hline & European & 90.33 & 17.54 \\
\hline \multirow[t]{4}{*}{ Language } & Afrikaans & 84.26 & 16.37 \\
\hline & English & 91.29 & 17.91 \\
\hline & Xhosa & 83.79 & 21.47 \\
\hline & Other & 100.00 & 35.36 \\
\hline \multirow[t]{5}{*}{ Marital Status } & Married & 90.00 & 19.21 \\
\hline & Widowed & 88.74 & 19.00 \\
\hline & Divorced & 89.00 & 21.32 \\
\hline & Separated & 81.75 & 9.00 \\
\hline & Never married & 80.37 & 17.47 \\
\hline \multirow[t]{5}{*}{$\underline{\text { Health }}$} & Excellent & 82.58 & 15.42 \\
\hline & Good & 89.57 & 19.64 \\
\hline & Fair & 85.79 & 19.74 \\
\hline & Poor & 84.00 & 18.12 \\
\hline & Terminally ill $(n=1)$ & 104.00 & - \\
\hline \multirow[t]{4}{*}{$\underline{\text { Religiosity }}$} & Very religious & 85.35 & 16.83 \\
\hline & Regular worshipper & 87.00 & 19.33 \\
\hline & Occasional worshipper & 93.15 & 23.46 \\
\hline & Not active & 85.71 & 26.86 \\
\hline \multirow[t]{4}{*}{ Education } & Part Secondary & 84.33 & 19.16 \\
\hline & Finished Secondary & 92.40 & 18.84 \\
\hline & Part Tertiary & 98.00 & 19.95 \\
\hline & Finished Tertiary & 87.56 & 15.49 \\
\hline
\end{tabular}

Table 3 shows the results of an ANOVA analysis of the Total Euthanasia Attitude Scale and the Biographical Variables. 
TABLE 3

RESULTS OF A ONE-WAY ANOVA OF TOTAL EUTHANASIA ATTITUDE SCALE (EAS) AND BIOGRAPHICAL VARIABLES

\begin{tabular}{|lccc|}
\hline Demographic variable & df & F & p \\
\hline Age & 4 & 1.706 & .153 \\
Language & 3 & 1.649 & .182 \\
Ethnic origin & 2 & 1.180 & .311 \\
Academic background & 3 & 1.545 & .207 \\
Marital status & 4 & 1.280 & .282 \\
Religion & 4 & 1.093 & .364 \\
Religiosity & 3 & 0.637 & .593 \\
Health & 4 & 0.835 & .506 \\
\hline
\end{tabular}

Table 3 indicates that there are no statistical differences between any one of the variables and the attitude a person had towards euthanasia.

Table 4 compares the means and standard deviations of those favouring and opposing euthanasia.

TABLE 4

MEAN DIFFERENCES ON THE TOTAL EUTHANASIA ATTITUDE SCALE (EAS) AND SUB-SCALES FOR PEOPLE FAVOURING (N=58) AND OPPOSING EUTHANASIA $(\mathrm{N}=62)$.

\begin{tabular}{|llllll|}
\hline Scales & & $\bar{X}$ & SD & df & t \\
\hline Total EAS & Favour & 103.00 & 10.78 & & \\
& Oppose & 71.29 & 9.19 & 118 & $-17.379^{* *}$ \\
EAS: General orientation & Favour & 46.02 & 7.52 & & \\
& Oppose & 28.50 & 5.02 & 118 & $-15.101^{* *}$ \\
& Favour & 27.67 & 4.42 & & \\
EAS: Patient rights issues & Oppose & 18.65 & 5.10 & 118 & $-10.329^{* *}$ \\
& Favour & 18.98 & 2.67 & & \\
EAS: Professional role & Oppose & 14.50 & 4.02 & 118 & $-7.138^{* *}$ \\
& Favour & 12.12 & 2.75 & & \\
EAS: Values and ethics & Oppose & 10.02 & 2.37 & 118 & $-4.501^{* *}$ \\
& Favour & 14.38 & 3.16 & & \\
& Oppose & 9.40 & 2.60 & 118 & $-9.449^{* *}$ \\
\hline
\end{tabular}

$* * \mathrm{p}=<0.01$

According to the mean differences on the Total EAS and Sub-Scales for People Favouring and Opposing Euthanasia (Table 4), people who favoured euthanasia had higher scores on the scale than those who opposed euthanasia. Respondents who opposed euthanasia consequently also had lower means on each of the five sub-scales. The differences between the two groups on the Total Euthanasia Attitude Scale and the sub-scales of the EAS were significant $(\mathrm{p}<0.01)$.

The mean difference on the PIL scores for people favouring and opposing euthanasia can be seen in Table 5. 
TABLE 5

MEAN DIFFERENCE ON THE PURPOSE IN LIFE TEST (PIL) FOR PEOPLE FAVOURING (N=58) AND OPPOSING EUTHANASIA (N=62).

\begin{tabular}{|c|cccc|}
\hline & $\bar{X}$ & SD & t & $\mathrm{p}$ \\
\hline Favouring Euthanasia & 104.74 & 12.73 & & \\
Opposing Euthanasia & 100.46 & 11.57 & -1.925 & .057 \\
\hline
\end{tabular}

It can be seen that those in favour of euthanasia had a slightly higher mean score on the PIL than those who opposed euthanasia, but the difference was not statistically significant.

Results of the Pearson Coefficient correlation between the Total EAS, sub-scales of the EAS, PIL and some biographical variables are seen in Table 6.

\section{Table 6}

Pearson correlation coefficient results between Total Euthanasia Attitude Scale (EAS), sub-scales and some biographical variables.

\begin{tabular}{|c|c|c|c|c|c|c|c|c|c|c|}
\hline & 1 & 2 & 3 & 4 & 5 & 6 & 7 & 8 & 9 & 10 \\
\hline 1 & - & & & & & & & & & \\
\hline 2 & 0,085 & - & & & & & & & & \\
\hline 3 & $0,910 * *$ & 0,024 & - & & & & & & & \\
\hline 4 & $0,859 * *$ & 0,106 & $0,711 * *$ & - & & & & & & \\
\hline 5 & $0,657 * *$ & $0,229^{*}$ & $0,383^{* *}$ & $0,577 * *$ & - & & & & & \\
\hline 6 & $0,541 * *$ & $-0,006$ & $0,374 * *$ & $0,423 * *$ & $0,345 * *$ & - & & & & \\
\hline 7 & $0,671 * *$ & 0,029 & $0,736 * *$ & $0,390 * *$ & $0,248 * *$ & $0,276 * *$ & - & & & \\
\hline 8 & $0,225^{*}$ & $-0,003$ & 0,178 & $0,190 *$ & 0,167 & $0,279 * *$ & 0,092 & - & & \\
\hline 9 & 0,117 & $0,225^{*}$ & 0,018 & 0,067 & $0,183^{*}$ & $0,208 *$ & $-0,011$ & 0,109 & - & \\
\hline 10 & 0,065 & $-0,065$ & 0,113 & $-0,001$ & $-0,048$ & 0,072 & $0,204^{*}$ & $-0,076$ & $-0,061$ & - \\
\hline
\end{tabular}

Note: 1 Euthanasia Attitude Scale (EAS) total

2 Total Purpose in Life Scores

3 EAS: General orientation

4 EAS: Patient rights issues

5 EAS: Technology

6 EAS: Professional role

7 EAS: Values and ethics

8 Age

9 Ethnic origin

10 Religious belief

According to Table 6 there was a significant correlation between the Total EAS and the subscales: General Orientation, Patient Rights Issues, Technology, Professional Role, and Values and Ethics. Of the biographical variables, age was the only variable that correlated significantly with the Total EAS. It showed that the older a person becomes, the more he or she will favour euthanasia. While age correlated significantly with the EAS sub-scales of Patient Rights Issues and Professional Role, religion correlated significantly with the EAS sub-scale of Values and 
Ethics. This signifies that different values and ethical criteria exist amongst different religious groups. Ethnicity correlated significantly with the EAS sub-scales of Technology and Professional Role, suggesting that people from different ethnic backgrounds will see the responsibilities of professionals and the use of technology differently. Ethnicity was also the only biographical variable that correlated significantly with the Total PIL scores, which indicates that people from different ethnic backgrounds have different meanings and purpose in life.

Table 6 furthermore shows that the EAS sub-scale of Technology correlated significantly with the mean PIL score, indicating that the higher a person's view of his or her purpose in life is, the more he or she will consider the usefulness of technology.

\section{DISCUSSION}

Research (Bachman et al., 1996; Blendon et al., 1992; Cicerelli, 1997; Rogers, 1996; Twycross, 1990) indicates that older adults are more negatively disposed towards euthanasia than the general population. This study, however, found a positive correlation between age and the acceptance of euthanasia. A plausible explanation for the reversal in expected results for age in this study may be attributed to the fact that the subjects were all residents of homes for the aged. Billing (1987) argues that the social system in which older adults find themselves is of vital importance in their attitudes towards life.

Pearlman and Ryan-Dykes (1986) estimate that more than 50\% of older adults who are residents in homes for the aged no longer function independently and rely on others for care and support. This dependency and the continuous exposure to the pain, suffering, illness and death of other residents may cause older adults to view themselves as less in control of their lives, environment and circumstances (Biggs, 1993; Heckhausen 1999; Strumpher, 1992) and therefore more exposed to the mercy of others. The older section of the participants would, according to this theory, be more exposed to the experience of pain and the deaths of others and would therefore be more in favour of euthanasia.

While Comaz-Diaz and Griffith (1988), Hessing et al. (1996) and Lee et al. (1996) argue that attitudes toward life and death are socio-culturally based, culturally specific and influenced by a person's ethno-cultural identity, this study found no statistically significant differences in the opinions of people from different ethnic backgrounds. Social reality in South Africa is such that few African people are untouched by urbanisation, industrialisation, as well as the pressures and demands caused by a shift away from traditional beliefs, values, social structures, customs and the influences of acculturation (Donald \& Hlongwane, 1989; McKendrick \& Hoffman, 1990; Rautenbach, 1989). According to Havenga (1974), the modern person is falling prey to conformity, leading to the disappearance of definite differences between different ethnic groups, which could previously have been the source of culturally diverse views towards euthanasia.

Although ill people have been shown to be more approving of euthanasia than people with few or no serious health problems (Dacey \& Travers, 1994; Larue, 1996), poor health failed to relate significantly to the preference for euthanasia. A possible explanation for this could once again be the influence of the social system (Billing, 1987) in which older adults find themselves.

Contrary to the results in Table 4 that those in favour of euthanasia had slightly higher scores on the PIL test than those opposed to euthanasia, meaning was in general found not to have a significant influence on a person's view of euthanasia. This insignificance might be explained by the disengagement theory (Lefrançois, 1999), which stipulates that people progressively disengage as they get older by withdrawing from social, physical and emotional interaction with the world. According to Frankl (1960), this unresponsiveness and absence of experience can contribute 
towards a person's lack of meaning in life, resulting in an existential vacuum. The declining force of religion, traditional morality and tradition itself has resulted in the disappearance of many cultural values (Frankl, 1967; 1980). A lack or loss of meaning is often central to suffering and unhappiness (Baumeister, 1991).

\section{CONCLUSION}

What this study achieved was to prove that issues relating to end-of-life decisions are extremely personal and unpredictable. It cannot be assumed that the older a person becomes the more he or she will conform to religious dogmas and outlooks that condemn euthanasia. Furthermore, older adults' opinions cannot randomly be assumed to conform to those of the younger adult population. Health care practitioners should therefore be very sensitive to each person's motivation and reasoning behind his or her end-of-life decision.

While the results of this particular study failed to prove that culture and health had a significant effect on a person's view on euthanasia, the literature available on the subject indicates the contrary. It appears therefore that this field deserves more in-depth study (Anderson \& Cadell, 1993; Cicerelli, 1997; Koenig, 1993). In addition, there is a definite need, in the light of the ominous AIDS pandemic, for studies relating to the influence of this life-threatening disease on patients' attitudes towards end-of-life decisions.

Questions regarding the ethics surrounding medical decisions to end life will always be part of our society, not only because medical advances develop at an incredible pace, but also because human beings increasingly want to be more in control of their environment and their lives. It is therefore of the utmost importance that further research in the field of end-of-life decisions should be conducted.

\section{REREFENCES}

ANDERSON, J.G. \& CADELL, D.P. 1993. Attitudes of medical professionals toward euthanasia. Social Science Medicine, 37(1):105-114.

BABBIE, E. \& MOUTON, J. 2001. The practice of social research. Cape Town: Oxford University Press.

BACHMAN, J.G.; ALCSER, K.H.; DOUKAS, D.J.; LICHTENSTEIN, R.L.; CORNING, A.D. \& BRODY, H. 1996. Attitudes of Michigan physicians and the public toward legalizing physicianassisted suicide and voluntary euthanasia. New England Journal of Medicine, 334:303-309.

BAUMEISTER, R.F. 1991. Meanings of life. New York: Guilford Press.

BIGGS, S. 1993. Understanding ageing: Images, attitudes and professional practice. Buckingham: Open University Press.

BILLING, N. 1987. To be old and sad: Understanding depression in the elderly. New York: Lexington Books.

BLENDON, R.J.; SZALAY, V.S. \& KNOX, R.A. 1992. Should physicians aid their patients in dying? Journal of the American Medical Association, 267(19):2658-2662.

CHENEY, N.I. 1996. The problem of inadequately relieved suffering. Journal of Social Issues, 52(2):13-30.

CHOCHINOV, H.M. \& WILSON, K.G. 1995. The euthanasia debate: Attitudes, practices and psychiatric considerations. Canadian Journal of Psychiatry, 40(10):593-602. 
CICERELLI, V.G. 1997. Relationship of psychosocial and the background variables to older adults' end-of-life decisions. Psychology and Aging, 12(1):72-83.

COMAZ-DIAZ, L. \& GRIFFITH, E.E.H. 1988. Clinical guidelines in cross-cultural mental health. Toronto: Wiley.

CRUMBAUGH, J.C. \& MAHOLICK, L.T. 1969. Manual of instructions for the Purpose in Life Test. Illinois: Psychometric Affiliates.

DACEY, J. \& TRAVERS, J. 1994. Human development: Across the lifespan. $\left(2^{\text {nd }}\right.$ ed) Iowa: Brown \& Benchmark.

DARLEY, J.M.; LOEB, I. \& HUNTER, J. 1996. Community attitudes on the family of issues surrounding the death of terminal patients. Journal of Social Issues, 52(2):85-104.

DEVELOPMENT BANK OF SOUTH AFRICA. 1996. Population of South Africa: Updated estimates, scenarios and projections 1990-2020. Halfway House: Development Bank of South Africa.

DONALD, D.R. \& HLONGWANE, M.M. 1989. Issues in the integration of traditional African healing and western counselling in school psychology practice. School Psychology International, 10:243-249.

FRANKL, V.E. 1960. The doctor and the soul. New York: Alfred A. Knopf, Inc.

FRANKL, V.E. 1967. Psychotherapy and existentialism: Selected papers on logotherapy. New York: Washington Square Press.

FRANKL, V.E. 1980. Sê ja vir die lewe (Vertaal vanuit Duits: Der Mensch vor der Frage nacht dem Sinn, by F.E. Deist). Cape Town: Tafelberg.

HAVENGA, A.A. 1974. Antropologiese onderbou van Logoterapie. Pretoria: Universiteit van Pretoria. (Doktorale proefskrif)

HAYFLICK, L. 1987. Human longevity. In: BERGENER, M. (ed) Psychogeriatrics: An international handbook. New York: Springer.

HECKHAUSEN, J. 1999. Developmental regulation in adulthood. New York: Cambridge University Press.

HESSING, D.J.; BLAD, J.R. \& PIETERMAN, R. 1996. Practical reasons and reasonable practice: The case of euthanasia in The Netherlands. Journal of Social Issues, 52(2):149-168.

HO, R. \& PENNEY, R.K. 1992. Euthanasia and abortion: Personality correlates for the decision to terminate life. Journal of Social Psychology, 132:77-86.

HOLLOWAY, H.D.; HAYSLIP, B.; MURDOCK, M.E.; MALOY, R.; SERVATY, H.L.; HENARD, K.; LOPEZ, L.; LYSAGHT, R.; MORENO, G.; MORONEY, T.; SMITH, D. \& WHITE, S. 1995. Measuring attitudes toward euthanasia. Omega, 30(1):53-65.

KASTENBAUM, R. \& SCHMITZ-SCHERZER, R. 1987. Education for death. In: BERGENER, M. (ed) Psychogeriatrics: An international handbook. New York: Springer.

KOENIG, H.G. 1993. Legalizing physician-assisted suicide: Some thoughts and concerns. The Journal of Family Practice, 37(2):171-179.

LARUE, G.A. 1996. Playing God: fifty religions' views on your right to die. Rhode Island: Moyer Bell. 
LATIMER, E.J. \& McGREGOR, J. 1994. Euthanasia, physician-assisted suicide and the ethical care of dying patients. Canadian Medical Association Journal, 151(8):1133-1136.

LEE, Y-T.; KLEINBACH, R.; HU, P-C.; PENG, Z-Z. \& CHEN, X-Y. 1996. Cross-cultural research on euthanasia and abortion. Journal of Social Issues, 52(2):131-148.

LEFRANÇOIS, G.R. 1999. The lifespan. (6th ed) Belmont: Wadsworth.

MacDONALD, W.L. 1998. The difference between Blacks' and Whites' attitudes toward voluntary euthanasia. Journal for the Scientific Study of Religion, 37(3):411-426.

McKENDRICK, B \& HOFFMANN, W. (eds) 1990. People and violence in South Africa. Cape Town: Oxford University Press.

NANCE, C.H. \& RUBY, C.L. 1996. On gender role violations and judgements made about euthanasia: A research note. Journal of Social Issues, 52(2):105-117.

PEARLMAN, R.A. \& RUAN-DYKES, M. 1986. The vulnerable elderly. Journal of Gerontological Nursing, 12(9):15-18.

RAUTENBACH, E.A. 1989. Verwantskapstelsels, verstedeliking en die swart gesin. Stellenbosch: Universiteit Stellenbosch. (MA tesis)

ROGERS, J.R. 1996. Assessing the right to die attitudes: A conceptually guided measurement model. Journal of Social Issues, 52(2):63-84.

SCOTT, H. 1998. Assisted suicide and the South African Constitutional order. Responsa Meridiana, 1-17.

SEALE, C. \& ADDINGTON-HALL, J. 1994. Euthanasia: Why people want to die earlier. Social Science Medicine, 39(5):647-654.

SOUTH AFRICAN LAW COMMISSION (SALC) 1997. Euthanasia and the artificial preservation of life (Discussion Paper 71, Project 86). Pretoria: SALC.

STRÜMPHER, J. 1992. Die psigiatriesverpleegkundige begeleiding van bejaardes tot sinsbelewing. Port Elizabeth: Universiteit Port Elizabeth. (Doktorale proefskrif)

TWYCROSS, R.G. 1990. Assisted death: A reply. The Lancet, 336:796-798.

VAN DER MAAS, P.J.; VAN DELDEN, J.J.M.; PIJNENBORG, L. \& LOOMAN, C.W.N. 1991. Euthanasia and other medical decisions concerning the end of life. The Lancet, 338:669-674.

VAN RENSBURG, H.C.J.; PRETORIUS, E. \& FOURIE, A. 1992. Gesondheidsorg in SuidAfrika: Struktuur en dinamika. Pretoria: Academica. 